\title{
Self-Awareness and Social Change in Higher Education
}

\author{
Kuwi Hoi New (Corresponding author) \\ Department of Journalism and Communication Studies, Southern College \\ 15KM, Jalan Skudai, 81300 Skudai, Johor, Malaysia \\ E-mail: khnew@sc.edu.my
}

Mohamed Najib Abdul Ghafar

Department of Foundation Education, Faculty of Education

Universiti Technologi Malaysia

E-mail: mnajibghafar@gmail.com

Received: October 9, 2011

Accepted: November 4, 2011

Published: February 1, 2012

doi:10.5430/wje.v2n1p25

URL: http://dx.doi.org/10.5430/wje.v2n1p25

\begin{abstract}
This research examines the development of self-awareness in students as they strive to adapt themselves to their current environment. The significant social factors that immerge include; culture, religion, language; economic status, family integration and work experience. Also considered are the relationships of students with teachers and classmates in a more restricted academic context, a third concern is the theme of autonomy and how students adjust themselves to their field of study. Overall, these findings reinforce the important role of self-awareness as it helps students develop in an educational setting.
\end{abstract}

Keywords: Higher education, Self awareness, Society, Academia, Self

\section{Theoretical Background}

Education is by many scholars taken to be a field largely dedicated to practice (Dewey, 1938; Peter, 1966; Bruner, 1996; Alatas, 1998; Jenkin, Breen \& Lindsay, 2003; Dimitriadis and Kimberelis, 2006). However, there is the need for theory to provide a conceptual perspective to the challenges of practice. The word education has a rich and ubiquitous range of meanings, which makes it difficult to give it a precise definition. Some of the most influential philosophers the Western world, such as Socrates, Plato, John Dewey, Karl Marx, Sigmund Freud, Jerome Bruner and Jean Piaget, have pondered its function. The process of education informs learners of the customs of their society and allows them to interact with others. Etymologically, education means "a leading out" of what is already there in the pupil's soul (Spark, 1961). Education improves student's self esteem, improves behavior and acceptance of responsibility, all leading to a greater independence of skills (Houle, 1972; Rose, 1999; Seltzer \& Bentley, 1999). As John Henry Newman taught us in 1852 and as cited in Matheson \& Grosvenor (1999), institutions of higher education have their distinct role to play in modern world, with the transmission of knowledge as their basic mission. The Ministry of Higher Education (MOHE) in Malaysia takes as its mission the fostering of an educational environment that will lead to the development of academic and institutional excellence. It is its vision to make Malaysia a centre of higher educational excellence by the year 2020 (Morshidi, 2005; Zailan, 2007).

Sociology is a scientific discipline whose task it is to establish objective knowledge concerning social phenomenon (Wilkins, 1973; Hurn, 1978; Haralambos \& Heald, 1985; Etzioni, 1991; Mulkey, 1993; O’Donnell, 1994; Gellens \& Levine, 1995 and McIntyre, 2008). One of its major concerns is the better understanding of education. Education is often taken to be the investment in human, social and cultural capital (Moore, 2004; Bartlett, 2007 and Cooley, 2009). This economic model in the sociology of education originated with Emile Durkheim in the mid-nineteenth century and has been expanded upon by Talcott Parson in his "functionalism" (Vago, 1996; Moore, 2004; Rury, 2009; Ritzer, 2008). As a functioning social mechanism education must distribute citizens into appropriate social positions to perform necessary tasks (Moore, 2004; Cooley, 2009 and Rury, 2009). The sociology of education must produce knowledge about education in society and knowledge about society through education. Institutions of higher education are places where universal knowledge it taught in order to develop those habits of mind that are useful for individuals in any sphere of 
activity. Such social institutions are complex organisms that must allow for adaptation to new demands and circumstances (Archer, 1979; Dwyer \& Minnegal, 2010). Students are trained to think independently and as a consequence they become more confident in engaging in the academic and social activities on campus.

According to Dewey, education consists of well directed activities, where knowledge changes with renewed inquiries. In his theory of knowledge, humans become knowledgeable by becoming actively involved with the environment. It is the set of conditions that interact with individual needs, desires, purposes and capacities to create the experiences (Dewey, 1938 \& 1966). He further states that knowledge is practical and instrumental. That it is developed to solve problems that human being encounter in the world and leads to a more effective understanding of what is natural. Dewey finds that social relationships are significant not only for the development of social values but for the fostering of change in human thought and behavior. He views schools as the site where students actively pursue their desire to interact with others, co-operate and construct collective goals. Dewey's theory strongly supports the contention that education is essential for the emotional, intellectual, social and moral development of the individual within a democratic society, while educators are socially concerned individuals with a personal investment in cultivating the social relationships and habits of mind that lead the way to social change (Dewey, 1966).

Thus, education is the processes of actual experience and learning. Students learn to think while teaches guide them in the exchange process of shared experience. Schools should help students to learn to live and to work with one another in the development of their creativity, problem solving abilities, open mindedness and the like. Another great thinker, Bruner (1960) has stated that the creativity of "meaning making" in a cultural context is more important than training individual to perform tasks in a narrow way. He argues that through social interaction individuals are taught a way of life and the values that will enable them to be part of their society. Bruner (1996) has further stated that education happens in a special social context between people who create and transform meanings. The goal of education is to instill self-reflection in individuals and to help them construct their values. "Construct" here is taken to be a key word in the process of learning and growth of knowledge. As the pragmatists John Dewey, Peter Elbow, and Lev Vygotsky have stated, knowing is 'doing', and doing is what should be the central activity at institutions of higher education. And so it is this study takes guidance from these theorists, together with Jean Piaget, who has fostered a constructionist theory of education, which takes learners as being those who are intimately involved with the interaction between their experience, their ideas and their society.

\section{Method}

Qualitative in-depth interviews have been used to focus on the meaning and process of social experiences among college students; and they have been able to provide a rich descriptive product as their output. This method has been able to reveal the real experiences of the participants in a college environment. The in-depth interviews have been carried out on a sample consisting of 15 Malaysian students age 19-23. The purposive sampling is used in the research in order to provide a clear idea of the type of students who are being studied. This study makes use of conveniently obtained participants, students from all faculties, who have enrolled for diploma courses having the duration of study two years and four months, and have an entry requirement of an S.P.M or equivalent qualification, with at least three credits plus a pass in Bahasa Malaysia.

\section{Results and Discussions}

Generally, the participants reported several themes that can be associated with self-awareness as they strive to adapt themselves to their current environment. Themes within this meta-category included (a) social, (b) academic, and (c) personal. These three themes illustrate that self-awareness always developed through students experiences, allow individuals to know themselves from people and environment they associated with.

Three themes emerged regarding the participant's self-awareness. Their responses revealed that their capacity to know themselves is very important in helping them to progress and develop from one stage of life to a better one. Students having a good understanding of their social environment and character will know themselves better and be able to note their own advantages and disadvantages in their advancement. This is consistent with the arguments that the students are conscious of their social situation and condition, know who they are and whom they are dealing with, they can add this experiences they gained from the past to know what autonomy they have at present situation, and then only are they able to responds to their surroundings affectively. We are told by Cargan \& Ballantine (1985), Johnson (1996), Schaefer (2000), Goleman (2006), Gonyea (2006) and Kottler \& Carlson (2010). Beyond this, Duval \& Wicklund (1972), Batson (1991), Tudge, Shanahan \& Valsiner (1997) and Vaughan \& Hogg (2008) have contended that individuals cannot react if they do not know their limitations and abilities. If they understand their difference from others, it will enable them cut short the time taken for trial and error in maturing. Self-awareness leads to individual adaptation to change, to new and better means of coping of life challenges (Brehm \& Kassin, 1990; Muuss \& Porton. 1998; Gorrod et al.. 2002; and Vaughan \& Hogg, 2008). 


\subsection{Society}

This theme emerged from the data analysis of the field's interviews of the college students. The theme has four sub-categories. These are the Family Integration; Culture, Religion and Language; Economic Status and Working Experience. These social characteristics are holistic in nature and function in the interactions among individuals in a group. They are basic to the human experience of interacting with other people in social groups where the contact occurs before or when students enter college. This social experience is very important and it affects a student's ability to adjust to new social contexts. Here are some examples of quotations from student interviews; one participant said that, "I feel warmth in this department ... everyone seems so nice to me. I've integrated comfortably. Here, everyone has their goals, different aims and even personalities. I interact with others. I can stay in this small community. I think I should be able to cope in the future." Another participant expressed it this way, "This type of learning environment is better than in secondary school. In the hostel it is quite in the middle of night. I love this hour very much." Another participant offered a similar explanation, "I think this college has a nice garden and field. It is good for studying. But I think lecturers here are nice too." One participant supported this by saying, "Now we have to do it ourselves, the teachers don't tell how to do it. For example doing a group project, the teacher gives us the topic; assigns the group members (sometimes we can choose the members) and the deadline to pass up the project paper. At the beginning I panicked. I had to do all by myself."

This study revealed that a new social setting is especially relevant to the adaptation of college students. An understanding of the characteristics of social environment categories may contribute significantly to the understanding of societal problems faced by researchers in education inside or outside the field. Student social environment is described in social theory as one of the important environments that humans inhabit in the social world (Robinson, 1997; Lau, 2003; Salter, Junce \& Irvin, 2004; Ashley \& Orenstein, 2005; Newman, 2006 and Rury, 2009). The category social environment is found in the literature to be very important to human interaction. These are relevant quotations from the participants. One said that, "College is easier to adapt to. Friends are very good and friendly. Before when I worked I also had to adjust to the new condition. To me college environment is easier to adjust to." Another stated, that "Here, time is more flexible; you can plan your time. I like it here because I can arrange my work. I like here because it is more like a society." This is supported by another saying that "The learning environment has changed. When I came to this college, everybody was studying and they were focused in class. Environment is very different." While yet another participant stated that, "I do not have the problem of adjusting to the environment. I am able to communicate and having the sense of closeness. It's not so commercialized. Other college or university students always compare their performances and tend to be more conservative." One participant said that "I had no problem to adjust to the environment, the people and cultural is just like ours. No problems at all."

Data analysis from field interviews reported that in self-awareness of one's environment and experiences helps students make better judgments and evaluate better how to take the next step. Social contexts include family integration; economic status; culture, religion and language, work experience, etc. This is supported by the findings of Weidman (1989), Schriver (2004), Cheng (2005), Goleman (2006) and Adams \& Galanes (2009), who report that the term "social person" refers to an individual with the ability to think, act and manage his- or herself socially and to develop harmonious interpersonal relationships effectively. The elements of social awareness, as has been stated, include family, culture, religion and language, economic status and work experience. These elements have emerged in the field interviews.

\subsubsection{Family}

In this research, family refers to two or more persons, including the householder, who are related by birth, marriage or adoption and who live together as one household. It is in families where individuals acquire competency in ways to communicate, a sense of right and wrong, basic beliefs and the competency to behave in daily life (Ashley \& Orenstein, 2005; Edgar \& Sedgwick, 2005; McIntyre, 2008; Smith \& Riley, 2009 and Rury, 2009). This study finds that the family significantly influences individuals in their value judgments and moral reasoning. As suggested by Gecas \& Seff, 1990; Mann (2003) and Hughes \& Kroehler (2009), the family has the great influence on future life goals, fundamental behavior codes and the core values of an individual. Families cooperate economically to care for the young (Gubrium \& Holstein, 1990; Lauer \& Lauer, 2000 and Hughes \& Kroehler, 2009). There are supportive quotations from the field interviews, such as; "Papa gave me one idea: not everyone will like you. Papa said you do not have to explain. So, I do not explain." One participant indicated that, "It should follow my family's teaching. My values are mostly from my parents. That's why we need a set of values to guide us. It will be the guidelines for us to make judgments." Another participant supported this by saying, "As a big brother of three children in the family; I think I should lessen his burden. So, I decided to work and earns for living, at least I am not asking for money from my parents. I will take care of them, 
as the elder brother. I will think of my sisters', my family and our future.” One participant expressed it this way, “... they converted to Christian without informing their parents. I will not do so. I think is bad to betray my family and have my own believe. I am 21 years old, but I respect my parents. I do not want them to feel hurt or sad."

\subsubsection{Culture, Religion and Language}

Interestingly, another scheme emerged is culture that refers to the symbols and various ideas that shape a student's thinking and judgments in a social environment. Cultural is central to the understanding of social processes (Lauer, 1984; Clammer, 1996; Schaefer \& Lamm, 2003 and Vaughan \& Hogg, 2008). Cultural provides a context in which students experience and evaluate they lives. Culture fosters both stability and change by allowing students freedom of choice within a zone of relative tolerance. Hamilton (1987), Zanden \& Wilfried (1990) and Griswold (2008) describe culture as a dynamic system of influence and change. This study finds that students from different cultural backgrounds have different patterns of adaptation. Culture here is taken to be the means by which the socially constructed meanings that influence a college student's development are fostered. Cultures set a range of opportunities for development and define the limits of what is desirable (Calhoun, Zanden \& Wilfried, 1990; Light \& Keller, 1997, Arnett, 2007 and Griswold, 2008). These are three of the quotations that show the influence of culture; "I think it's a cultural difference. Compared to before, school culture is different from before; I'm from a good school. I'm from premier schools from primary one to higher secondary. It was very result orientated, competitive and stressful." One participant indicated that "Mother will not tell me she loves me ... No. she never shows it. Even when I have high fever and am seriously sick, she always act so coolly, but I know she care about me. I am used to it already. It always feels cool, and sometimes ... I hoped mother will give me present. But she didn't do so. She just can't show little love to me, I was so disappointed. I had tried so hard to gain her love, yet she treats me coolly." One participant described that "Taiwan culture and ours is totally different ... Their toilets are not smelly and they are dry - not wet water like ours. Toilets are so clean. In restaurants, if you put your bag down for as long as 3 hours, there isn't any problem. I observe the big difference."

In field interviews, most participants acknowledged that religion is important, helping in judgments and decisions. An example is the statement "I think each of us one way or another we must make judgments. It influences us in the judgments made. If I have problem I will pray to 'God of Mercy.' It influences me; good values are from my family and religion." Another participant stated that "Religion helps us to be better people; particularly in guiding us to make judgments and decisions." Another participant stated a similar explanation; "I believed that it is important to have my own believe. I will use this as a guideline to make judgments. When I believe in it, I will do it." Yet another participant stated "I pray. It is good. I think religion is important. To me one will feel scared that he will not do a thing without thinking, become more positive." This is in line with findings that show that religion organizes ways of thinking, feelings and acting (Stark \& Bainbridge, 1987; Warner, 1993; Neuberg \& Glasberg, 2005 and Hughes \& Kroehler, 2009). Religion performs are an impetus to social change. Social changes that are justifiable in religions terms is easier to accept and less disrupting than those with a purely secular basis, as found by Warner (1993) and Hughes \& Kroehler (2009). Religion offers a body of beliefs and practices that are concerned with the supernatural and the sacred. Some sociologists, however, have argued that religion can cause significant social change as suggested by Neuberg \& Glasberg (2005) and Holborn \& Haralambos (2008). Religion provides an individual with a believe system for understanding his or her existence, as well as a network of personal support in times of need (Light \& Keller, 1997; Smelser, 1988; Newman, 2006; Griswold, 2008 and Hughes \& Kroehler, 2009). Calhoun, Zanden \& Wilfried (1990), Tudge, Shanahan \& Valsiner (1997), Holborn \& Haralambos (2008) and Griswold (2008) also find that religion helps to provide consensus, which Parsons believes is necessary for order and stability in society. Religion has to do with those socially shared and organized ways of thinking, feeling and acting that concern ultimate meanings about the existence of the supernatural. This concurs with the findings when the participants said, "It is useful when I face some uncertain happening, like when my friend's brother died in an accident when he was 17 years old. Just before he met the accident, he was with us and then an hour later I was told that he died. So, I couldn't believe that." One participant explained his experience; "I believe in burning paper money, cars, houses, clothes for a beloved person who has passed away. I believed in them. There are many incidents that prove me right. I'm scared of ghosts. I never do a thing to hurt others."

The human ability to speak is a unique characteristic. When the students are well aware of their social environment, they are able to communicate effectively. Goode (1984), Zanden \& Wilfried (1990), Vaughan \& Hogg (2008) and Hughes \& Kroehler (2009) tell us that language is socially structured system of sound patterns (words and sentences) with arbitrary but specific meanings. Language is a powerful mechanism that can even influence sensory perception. Language can bring about enormous emotional change. Words can make someone happy, sad, disgusted, and angry or even incite him or her to violence. This study finds that students who are fluent in their language tend to speak confidently in their social interactions. While on the contrary, those who are poor in language tend to listen quietly in the context of group interaction. At the college level the classes are mostly conducted in English, yet many of the students are not fluent in 
English, Bahasa Malaysia or Chinese. As the one participant suggested, "I always try to find out the methods to learn something new. Sometimes it is because I am not good in language." Another participant supported this by saying "I think that is my problems. I was interviewed and the person-in-charge kept saying that my languages were poor, Malay, Chinese and English; all three languages." One participant explained that, "I am not so confident about studying in Singapore, as it is very advanced and it needs a higher level of English to study well. So, I think maybe I'll spend some time here to adjust myself to be able to learn by English." And one participant stated, "I have problems in expressing myself. I cannot explain and present my ideas effectively. I have problems. Language is one of the most serious problems." And one female participant said "I just did not understand English at all. It changed from Malay medium into totally English medium, I went crazy for that."

\subsubsection{Economic Status}

In this study it has been revealed that another key element in student social awareness is economic status. College students are rarely financially independent; students have to rely on their parents or guardians for their tuition fees and daily expenses. As a consequence, the financial factor directly influences their decisions and daily activities. The present study confirms the findings that young men and women of college and university age become less financially dependent on the family only when they start to play new roles, strive for greater autonomy and responsibility. This happens when students learn how to adapt to the world of work (Cargan \& Ballantine, 1985; Smelser, 1988; Zanden \& Wilfried, 1990; Sanderson, 1991 and Griswold, 2008). Here are some quotations from the field research: "No money then I went to work I had no money. So, I worked. I can now come back to study. While I worked I didn't save enough money. I had no money. Having no money to spend here is my main problem." Another participant described it this way, "but poor me, I cannot afford it because I have financial problems." And one supported this by saying "But living expenses are a problem. I worry. I spend a lot in college. I spend more money." One participant added, "In my courses, I need to purchase a lot of color and art papers. It is very costly, so sometimes we try to buy in a big numbers to get a lower price. We also know where to get the lowest price for certain materials. So, it helps to reduce our burden."

\subsubsection{Work Experience}

This study finds that it is quite common for college students, particularly those from average and lower income families, to work part-time while they are studying. This is supported by research done by Brinkeroff \& White (1985) Cargan \& Ballantine (1985), Sanderson (1991), Tepperman \& Richardson (1991) and Coleman \& Cressey (1993) and Clark (1996). Besides learning to get along with people, while formulating values and goals for their lives, the majority of students claim that they can work to earn some pocket money to buy things that they want; since their parents only support them by paying the tuition and basic daily expenses. The following are some quotations from the field interviews; "I went to sell clothes when I was in from 4 with my friends to get some pocket money. I did get some money." and another participant reported, "My problem is I need money for my expenses." One participant indicated that "I am not from a rich family, so I have to earn my pocket money and daily expenses." Another explained, "Last time, RM120 was still enough, but now everything increases in price, RM150 also still cannot cover the expense. So, I have to work part time to gain some pocket money."

There are some students who have to work a full schedule during weekends to get enough money. There are others who can work occasionally, for example when there is a computer fair, a special event or seasonal celebration like Hari Raya, Labor Day, and the like. All the interviewees have had work experience as part-timers during their study in this college. The results are in agreement with the research done overseas, which find that over $80 \%$ of the young people have held a part-time job by the time they leave high school. It is also found that the purpose of these jobs is mainly to obtain money to finance an active life and not for occupational training (Hall \& Hall, 1988; Pascarella \& Terenzini, 1991 \& 2005; O’Donnell, 1994; Barling \& Kelloway, 1999 and Grusec \& Hastings, 2007).

Work experience serves as a means of formal and informal socialization (Gellens \& Levine, 1995; Sandstrom, Martin \& Fine, 2003; Neubeck \& Glasberg, 2005 and McIntyre, 2008). College students recognize that academic socialization need not necessarily be socialization into one's lifetime occupation. Individuals must learn to be realistic, bridge the gap between present and future, besides learning to assume adult responsibilities and burdens; they must learn the realities of the job (Goode, 1984; O’Donnell, 1994; Berndt, 1996; Schaefer, 2000 and McIntyre, 2008). The workplace has the potential of socializing college students into their occupations and represents both the locale of harsh reality. Young people may work while continuing to live at home. Others become less financially dependent and take on new roles and living arrangements to achieve greater autonomy and responsibility. Students learn to adapt to the world of work by coping with job changes (Freud, 1938; Becker, 1986; Joseph, 1986 and Muuss \& Porton, 1998). Many of the participants have supported this conclusion by saying, "Working made me lost my confidence. The boss scolded me ... Working made me feel hurt, bad. It made me know studying is very important. Working made me loss my confident." 
Another participant explained, "I would say working experience is a good because it is just like living experience; one will have chances to mix around and learnt how to help each others in life." Another participant said, "When I work it is just like stepping into the real world. While I study than I know that working and study can be both quite different. Theory and practical might not be the same, so when I work now it is like complementing with each other." Another stated "I think some working experiences will help me to be able to appreciate what I have right now. I have learnt human relationships; how to serve people, how to be patient, how to understand other's feelings and thoughts." One added to this by saying "By doing part time projects I can practice and improve my skills. I cannot earn much but the experience of doing real things is very fantastic. Especially when the boss likes it and uses it, the satisfactory is there."

The other theme emerged from the field interview analysis, this study finds that experience with success and failure, a sub-category of self-awareness, takes place when students try to get to know their own ability and capacity, to adapt to new situations and his or her past experiences, particularly bad experiences. These factors affect significantly their ability to adjust smoothly to a new environment. The experience of hardship or failure among college students is found from field interviews. Students who have experienced the loss of a loved one have their awareness about themselves altered. The diagnosis of the impending death of a loved one requires an individual to reevaluate and re-adjust to a new definition of self. The responsibility for laying out the deceased family member and preparing for the funeral is especially traumatizing. During the replacement process family members must learn new behavior based on their new roles. This study helps to verify the work done by Tepperman \& Richardson, 1991; Harter, 1996; Muuss \& Porton, 1998 and Hughes \& Kroehler, 2009, who point out that the experience of dying changes a person's feelings and thoughts, and individuals learn to adjust to new experiences and rules in addition to learning new management skills and conflict resolution strategies. Here are some relevant quotations from the field interviews with students who experienced a death at the young age. One participant described it this way, "My elder uncle died of EIDDES, (mosquitoes) while he was on the way to be sent to General Hospital Johor Bahru. Both my grandparents were too sad, my granny had passed away two weeks after my uncle. He died at 30 plus ..." Another participant included that, "I remember when I was 3 years old, mother gave birth to a brother, but he died after two days. I always feel sorry to my mother, sorry for not sharing her pain and sadness. I think I should love her more, she was hurt deeply.” One participant recalled his experience by saying, "My grandmother, just before she died she called me and asked me to further my study. She loved me very much. I am the only grandson, I even dream of her after she had died." One female participant added that "My father passed away when I was 17, my mother fainted in front of me."

This study finds that besides the event of death, students have also experienced serious illness of family members, living apart from their family, being bullied at young age and failure in major examinations, and that these have all contributed to their self-awareness. This is supported by studies done by Anderson \& Carter (1984), Coleman \& Cressey (1993) and Hoover (2002). Students tend to imprint those experiences on their mind and this affects their social relations in the later life. The worst is that it might bring on psychological problems such as depression, a psychological disorder characterized by negative moods such as feelings of sadness and despair, low self-esteem, pessimism, lack of initiative, and slowed thought processes (Anderson \& Carter, 1984; Brehm \& Kassin, 1990; Coleman \& Cressey, 1993; Alcock, Carment \& Sadava, 1994 and Hoover, 2002). This research finds that some students have gone through such bad experiences from young age. The following are some of the relevant quotations from the field research, one participant stating, "I cried. I cried. I felt bad ... it was because I was not good. I was very sad because my knowledge and experience were not to the right level. I think I should upgrade myself. I think I should go to study some more." Another participant said, "They beat me once, two bullies in primary six. Psychologically, emotionally they purposely said something bad. They were very fierce and scary. When I saw them it was just like seeing a tiger. Like a tiger. It scared me. I do not want to mix around because of this. I was very scared." Similarly another participant indicated "that's why I cry a lot. At the initial stage, I use to cry more. I do not know how to handle things ... I cried quietly, when I am alone." And she further explained;

"It is depression. My sister has this since she was in her senior one ... My sister is a quiet and homely person. So, in her senior one, she burst out and went crazy. All of a sudden, all of us were so helpless. We cannot take it and do not know how to handle it. My mother tried to blame herself and my father turned to be a speechless person ... So, later my sister stopped going to school and she was sent to Singapore for treatment and stayed there for a period of time. My mother stopped working and then ... We also moved to a new house for a change in environment ... it is too much of stress to study there ..."

Another participant indicated that,

"My mother, she had depression when I was a boy. She used to hurt me, she even uses the iron to hurt me, you know. I ran away from home many times. I couldn't stay at home, I hated her. Later on, I came to know 
that it was me; she had post natal depression which drove her out of her mind. She just cannot control herself. The moment she saw me, she got angry and impulsive. Then, she was sent to hospital for treatment, and I was sent to my aunt house ... When my mother asks me for forgiveness, at times, I still really hate her. I hate her for not loving me, for hurting me and causing me living so far away ..."

This study also reveals that failure in studies has also caused some of the interviewees to have very low self-esteem and negative judgments of their abilities. One participant reported, "Everywhere I go nobody wants me. I hate science but everyone requires mathematics ... I fail all calculation subjects. I dislike mathematics. I failed mathematics. Mathematics failed again ..." Another said, "I think so. I am less confident in doing things, and I am scared to go on stage even though like the feeling of being on stage. I appreciate what I have more, and I will grab any opportunity that I have," and another, "I felt guilty too when I failed my Algebra and Calculus. I cried many times, I even make appointment with the lecturer to give me extra lesson at McDonald. I will stop for a semester, to come back to enroll for this two subjects later on. I must get it as to get my Diploma." One male participant remarked, "I have very low self esteem. I am ashamed of my bad result; I even had 'closed up' myself from others. I was scared that people knew about my bad result; I was scared that they would look down on me; I was very shy about everything. I wanted to forget about the past and start as a new person."

\subsection{Academia}

The second major theme that has emerged from the data analysis is in academic or scholastic relationships. This relationship can be defined as an integrated network of enduring emotional ties, mental representations and behavior that connect one person to another over time and across space (Townsend, 1999; Mingle, 2000; Ashley \& Orenstein, 2005; Gonyea, 2006 and Grusec \& Hastings, 2007). It is found that a student's self-awareness in academic relationships is important in the process of social change. The findings show that there are two types of such relationships; faculty relationships and peer relationships. In college more learning is to be done through assigned work that the students do on their own. This is congruent with the research done by Hamilton \& Hamilton (2006) and Hughes \& Kroehler (2009).

\subsubsection{Faculty Relationships}

A few participants reported that they have talked to their teacher freely on any topic; but most students say they have limited topics to share with their teachers. They only talk to teacher on social topics such as hobbies, leisure, sports and fashion but not about serious matters. One participant remarked, "I will prefer to tell teachers because they will give me support and motivation. Teacher will share with me their experiences." Another participant further explained "In the past, there were no interactions with teachers. But here I have a lot of interaction with teachers." Another participant commented "I talk to teachers on social topic only. Sometimes we talk about my hobbies and interests such as photos and travel but not about my writing or personal matters." Another participant said "I feel self-conscious; I only talk about something relaxing or just chit-chat. We cannot talk about homework or study. Not something to do with study, always other than study." One reported "My impression is our teachers are always very busy. So I do not talk to them. I like to interact among students." One explained in an excited manner "No, not to teacher, it is difficult. I feel there is still a gap there. I can share something like a joke; it is okay but not an in-depth talk on a serious topic ... As for teachers, I only talk about something casual, jokes or funny stuff nothing serious, no way." This study finds that most students say teachers are teachers, and so they must respect them, with the result that there is a gap in the interaction among faculty and students in the college setting. Of all the interviewees, the Art \& Design students wish to build the closest relationship to faculty members, they hope that by doing so, the faculty will understand their ideas and designs better. One interviewee stated "This kind of interactive session is important particularly in doing design and creative art work. Teachers will understand our creative ideas and vice versa; as a student I can understand my teacher's style and expectation."

Interestingly, in this research, students were found to judge a faculty member by looking at his or her way of conducting classes and answering student questions. Students have their expectation of teachers as when an interviewee says: "She failed me. It motivated me. I realized that I must use the correct methods in my studies. I think because of this teacher, she failed me and woke me up. She fails me yet I appreciate her." One participant suggested "I think teacher's can do something; motivate, encourage, guide the students at least help them to improve themselves. I knew that round can't be changed into square, but it can be made into a better round shape." Another participant commented "They are good. Not so high academically. They are close to students. We can talk together, play together ... When teachers are concerned I feel happy." Another participant stated "I am satisfied, especially with the teachers who are very helpful, caring and passionate. The teachers, they are good. They give me support, courage. He has students at heart." Another remarked "The teacher must always put themselves into our position. Don't do thing which you don't want students to do. Treat students as sincerely as can be ... As we grow up, I think communication is more important, teachers should tell students their expectations while as a student I know what I should do in return." 


\subsubsection{Peer Relationships}

In this study, it is found that students really enjoy getting together with their peers for light and casual talk. They love to talk about celebrities, fashion, computer games, hobbies, music, movie, food and family. Peers have a significant influence on musical tastes, personal adornment and choice of entertainment idols (O'Donnell, 1994; Schaefer, 2003; McIntyre, 2008 and Hughes \& Kroehler, 2009). College students take friends seriously, and after their family, friends are most important to them. They also learn from each other and share their problems. One participant reported "friends always encourage me." Another said, "I have secondary friends. We learned well from bad; right from wrong from one another. We still contact each other." Other participant reported, "When I am in college, friendship grows deeper than in high school. We talk to each other more often when you have buddies. I talk to my friends when I have problems." One participant stated "We go to sports events and discuss our studies. I have group of friends whom I go to games, singing and tea with. With some friends I talk about my future plan. Some, I talk about my problems." Another claimed "He is one of my friends whom I can ask for suggestions and opinions. Not my boyfriend, he is not able to help me. Even though he seems to be strong physically; tall and fit but he cannot provide me good ideas or mature suggestions." Yet another said "Most of the time, I go for tea with friends at $8.00 \mathrm{pm}$ and come back at 12.00 mid night. We just have a cup of tea each, and then talk about something, face to face that's all. We are happy. Sometimes I listen to their problems ..." Another said "I will get suggestions from friends, like for my final project; I will tell friends about my ideas. Some of them are from the Business School, Art and Design, Chinese Studies and many more. We talk about everything; music, fashion, movie, food and family." Another reported "About make-up, fashion, future plan, and guys ... we talk about guys too. This is normal. We cannot talk about them to parents. I need friends. They are very important to me. I share with them my hobbies, problems and much more;" and another said, "Peer studies are more effective to me, he will write notes and teaches us, and from there we learn;" and yet another, "I will do better if I'm together with friends. I think I learn from my friends; like Z.S., he can communicate with people very well. I learn from them."

This research finds that of the total interviewees there are six students who have the habit of drinking beer during their college lives. There are as well young men and women who choose to go with friends for beer and some even have it on the college premises. They claim that it can actually help them to relieve stress and get ideas for their writing. According to Strauss (1976), Schuckit (1984), Coleman \& Cressey (1993) and Goode (1994), alcohol has the great capacity for alleviating pain, relieving tension \& worry, and encouraging relaxation and good will toward others. Alcohol is called a depressant because it depresses the activity of the central nervous system of human. It is used for the release from academic pressure and despair among young people; it is a form of 'escapism'. These results support the statement made by Schaefer (2000), Slavin, Hurley \& Chamberlain (2003) and McIntyre (2008) that research has shown that peers increasingly play an important role in socialization process of youngsters who are of a similar age group. Muuss \& Porton (1998), Barber, Eccles \& Stone (2001) and Hughes \& Kroehler (2009) find that alcohol consumption in early adulthood is significantly correlated with a student's social identity. This study finds that nearly half of the college students who drink say that they usually sing when they drink and that being able to do so is a good reason for drinking. Many college students have their first drinking experience earlier than in the past and the drinking habit is becoming more common among young people. This is supported by Strauss (1976), Bassis, Gelles \& Levins (1982), Schuckit (1984) and Coleman \& Cressey (1993). This study finds that drinking is accepted among the families of the interviewees. Anderson \& Carter (1984), Goode (1994), DeCenzo \& Silhanek (2002) and Vaughan \& Hogg (2008) have pointed out that the behavior of young people changes once they get use to the intake of alcohol. For example, one participant described their position explicitly; "Sometimes, I drink beer. I think beer can help me. I was drunk the last time when I drink. My first was offered by my father during New Year, then later at birthday parties and special occasions. My father also drinks beer. Father knows that I drink in the college. I can control myself." Another participant said "I had two glasses. I tried to cut down, so as for cigarettes. I am too used to it; I started smoking when I was in lower secondary. I tried to forget my problems and I felt good with it. Now, my girl friend, she hates that smell, so I tried to eat sweets and reduce the number of cigarettes." One participant stated "I like it; it is better for us to talk about something with beer, we can communicate in that environment and feel more relaxed."

Besides the intake of alcohol, this study also revealed other questionable habits among college students. Many students have been found to have the smoking habit. Tobacco contains nicotine which is addictive and is a stimulant that raises blood pressure, speeds up the heartbeat and gives the user a sense of alertness. Smoking and drinking habits are becoming more frequent among college students (Bassis, Gelles \& Levins, 1982; Smelser, 1988; Tepperman \& Richardson, 1991; Coleman \& Cressey, 1993; DeCenzo \& Silhanek, 2002; Newman, 2006; McIntyre, 2008 and Vaughan \& Hogg, 2008). Students learn to smoke through socialization, the need for escape and the lack of self-control. All the male smokers admitted that they had smoked from a very young age and were influenced by friends, with most 
smokers finding it difficult to stop. This research finds that college students smoke and drink as a supposed means to prepare themselves for entry into adulthood. As this interviewee says, "I may say something that normal me dare not say. I went for a beer last night with girls from this college. I wanted to be grown up. I tried smoking; drinking beer and I went travelling by myself. I hoped to get freedom; be a backpacker. I tried to check in to Genting Casino and to book a room there. So, I went to pub for beer. Being an adult I can do many things. I am independent."

This study also reveals that not all peer relations are smooth and happy; some of the interviewees have had the experience of quarreling with close friends and had to find ways to overcome serious problems to continue their relationship. As Brown, Eicher \& Petrie (1986); Muuss \& Porton (1998), Hodges, et al. (1999), Grusec \& Hastings (2007) and McIntyre (2008) find in their research, peer groups allow their members to be assertive in a way that may not possible elsewhere. In this research, it is found that young people who are accepted by their peers and who have established friendships with classmates are more likely to enjoy a relatively safe college environment. They mimic their friends to maintain a meaningful relationship with their social equals, as well as with themselves. One participant noted that "Friends, they respect me because I am older than they are. I have many friends." Another said, "We just have a cup of tea each, and then talk about something, face to face that's all. We are happy. Sometimes I listen to their problems."

It has been confirmed that among college students peer influence is often greater than any other socialization source. At this stage of life, their peer group provides them valuable social support as they move toward independence from their parents. It has the greatest influence on lifestyle, appearance, social activities and dating. Alcock, Carment \& Sadava (1994), Tischler (1996), Calhoun, Light \& Keller (1997) and Vaughan \& Hogg (2008) argue that peer groups are the most effective means for molding the behavior of young people, particularly those whose parents do not provide consistent standards, a moral code, personal guidance or emotional support. This prompted another two participants to say "I will discuss it with my friends or those who are more socialize and whose family backgrounds are similar to mine. In my area most people are poor; we talk about how to make money. There are group friends who are interested in cars, fish, computers and swimming and so on. I talk about my career with people who have had common experiences. But I think encouragement from family and friends are important too." And another said "To me, friends are very important. I want harmony and no misunderstandings. If the person refuses to talk, I will never have a chance to get over it. I get my confident from activities. I meet friends and we get to know ourselves."

\subsection{Self}

The personal characteristics of the autonomous self constitute the last theme that has emerged from the field interview. This study shows that generally speaking students are happy to come to college for their studies. As they contend, they have more freedom and free time to "do their own thing". Students enjoy the lecture system, where they can attend lessons and have a break between lessons. Most of them use this time to get together with friends and some even use it for doing research in the library or browsing the Internet for topics of personal interest. Also, in the college setting, students are given more autonomy in terms of attending lectures and doing their projects. For example, in high school, students are required to be in class listening to teachers; while in college, students are free to make some adjustment so long as they attend three fourths of the class hours. They are given opportunities to speak, to make presentations and participate in class, not required merely to be passive learners. They are active learners in most classes in the college setting. For them this is autonomy and they love it. College students developed a greater sense of autonomy from adults by forming relations with peers. Parents no longer have as much influence; now college students have greater freedom to focus on their self-development' as revealed in research done by Hamilton (1987), Calhoun, Zanden \& Wilfried (1990), Light \& Keller (1997), Neuberg \& Glasberg (2005), Arnett (2007), Griswold (2008) and Kottler \& Carlson (2010). Following are some quotations from the field interviews for example, "Now I have my own time, after 2 hours lecture, I have my time to do research, it is less tension." Another participant stated "College allows us to make choices and participate in what I like, I have more freedom, so of course I like here." Another reported "I like it here because I can arrange my work ... College is more similar to society. You can move around and have some freedom to do your own things. For example, I like to go to the Internet for music, videos etc. ..." One participant supported this by saying, "I love freedom. I dislike being restricted. I believe in study one should be able to handle issues or unexpected things confidently ... I think it is given enough space for us to progress." Another explained, "You know we are very young, we should be allowed to do the things we like."

The field interview data offer in depth explanations of how college students develop their self-awareness by gaining autonomy in college, they have more spare time and time with friends, unmonitored by either parents or school teachers. They start to associate more with other individuals like themselves. Peers can be cooperative and discuss ideas that promote change. Studies done by Cargan \& Ballantine (1985), Tepperman \& Richardson (1991), Rogoff (1997), Killen \& Wainryb (2002) and Grusec \& Hastings (2007) point out that the cooperative organization of social events will lead to 
the formation of social constructs. College allows students to have autonomy, which motivates them to learn. The findings of this research confirm the contention that college students desire greater opportunities for autonomy and a less adult-controlled environment. College students are attempting to gain control over their own selves and freedom from adults, as pointed out by Gellens \& Levine (1995) Muuss \& Porton (1998) and Gorrod et al. (2002). Here are some supporting comments: "I found that it is difficult because I have to wait for friends. Now, I just walk in campus. I love it. We have a walk in the evening, whoever is free can just starts walking and later someone will join in. It is simple and nice." Another reported "I just want to be free. Free to do anything that I like. Go anywhere I wished. That's all." And one stated, "I love the feeling of free and easy."

Interestingly, in today's society, individuals, particularly college students, are offered a variety of environments. This study reveals that in the relationships among individuals, college students need to take a more active part in selecting and accumulating elements in the environment that are most suitable for them. Students need the ability to select among social influences. They are not merely passive followers; they can play active roles, particularly with the ones nearest them. In this study it is found that being aware of their capacity to accomplish things helps students to select the best for themselves. According to Mulkey (1993), Innes (2004) and Cooley (2009), self change is necessarily local and small in scale. In choosing their environment, students are free to choose which groups he will belong to in their college environment.

\section{Concluding Remarks}

In this article, the researcher has outlined the elements of the theme awareness into three major themes; social, academic and personal. These elements influence the actions of individual college students and how they interpret and respond to the circumstances of their environment. When students enroll in a college to further their studies, they bring with them the values and beliefs of their past experience and are obliged to fit them into the new environment. Awareness of the social context aids the student in attaining a better response to future encounters. The social environment plays a key role in providing a contextual setting for the relationships that will influence the course of self development. Students tend to be interactively associative with their environment. Social awareness has been proven to be closely linked to the other elements of society. As students become aware of their selves they are able to function better as one of the elements in their social environment.

In higher education, social change does not happen in isolation. Students especially must be part of the struggle, and an important task of people working in educational institutions is to help them to participate as actively as possible. Today, people are living in a competitive economy where businesses and individuals are continually seeking advantages and higher profits (Morshidi, 2006 \& Zailan, 2007). This study argues that efforts to improve the self-awareness of college students are an important part of the long term struggle to create a more equitable society in the country Malaysia. It also suggests that students, especially in institutions of higher education, must be an integral part of struggle to help in this improvement, so that they can become participating citizens in a democratic society.

Social change results only when people take it upon themselves the task of getting involved in making a difference. Humans live in groups and are sociable by nature. There are two key factors that influence human development; genetic and social experiences. Each person creates his or her 'self', which is the sum total of a person's conscious perception of his or her own identity as distinct from others, and it is not static but develops and changes throughout one's life. As a human evolves in society, the self tries to take something from others and at the same time others may try to take away something from the self, as stated in Bilton et al. (1981), Etzioni (1991), Turner (1994) and Rury (2009). There are some difficult socialization challenges that are encountered and it is hoped met during the college experience in order to help students become well-integrated and contributing members of society in their adult lives.

\section{References}

Adam, K. \& Galanes, G. J. (2009). Communicating in Groups: Applications and Skills. (Seventh Edition). New York: McGraw Hill Higher Education.

Alcock, J. E., Carment, D. W. and Sadava, S. W. (1994). A Textbook of Social Psychology. (Third Edition). Canada Inc.: Prentice-Hall.

Alatas, S.H. (1998). The Philosophical Foundation of General Education. The Development of the Intellect. Journal of Social Sciences \& Humanities. July 1998. No. 53. UKM: Bangi.

Arnett, J. J. (1998). Learning to Stand Alone: The Contemporary American Transition to Adulthood in Cultural \& Historical Context. Human Development, 41, pp295-315. http://dx.doi.org/10.1159/000022591 
Arnett, J. J. (2007). Socialization in Emerging Adulthood From the Family to the World, from Socialization to Self-socialization. In Grusec, J. \& Hastings, P. D. (2007). (Editors). Handbook of Socialization Theory \& Research. (pp 208-231). The Guilford Press. New York \& London,

Anderson, R. E. \& Carter, I. (1984). Human Behaviour in the Social Environment. A Social System Approach. New York: Aldine Publishing Company.

Archer, M. (1979). Social Origins of Education Systems. London: Sage Publications.

Ashley, D. \& Orenstein, D. M. (2005). Sociological Theory: Classical Statements. (Sixth Edition). Boston: Pearson Education.

Bartlett, S. and Burton, D. (2007). (Editors). Introduction to Education Studies. London: SAGE Publications.

Barber, B. L. \& Eccles, J. C. \& Stone, M. R. (2001). Whatever happened to the Jock? the Brain \& the Prince? Young adult pathways linked to adolescent activity Involvement and Social Identity. Journal of Adolescent Research, 16 (5). pp429-55. http://dx.doi.org/10.1177/0743558401165002

Barling, J., \& Kelloway, E. K. (1999). Young Workers: Varieties of Experience. Washington, DC: American Psychological Association. http://dx.doi.org/10.1037/10309-000

Batson, D. (1991). The Altruism Question: Toward a Social - Psychological Answer. Hillsdale, New Jersey: Erlbaum.

Bassis, M. S., Gelles, R. J. \& Levins, A. C. (1982). Social Problems. New York: Harcourt Brace Jovanovich, Inc.

Becker, H. (1986). Doing Things Together. Evanston, IL: Northwestern University Press.

Berndt, T. J. (1996). Transition in Friendship \& Friends' Influence. In J. A. Graber, J. Brooks-Gum, \& A. C. Petersen (Eds). Transitions through Adolescence: Interpersonal Domains \& Context. Mahwah, New Jersey: Erlbaum.

Bilton, T., Bonnett, K., Jones, P., et al. (1981). Introductory Sociology. (Second Edition). London: Macmillan Press Ltd.

Brehm, S. S. \& Kassim, S. M. (1990). Social Psychology. Boston: Houghton Mifflin Company.

Brown, B. B., Eicher, S. A., \& Petrie, S. (1986). The Importance of Peer Group 'Crowd' affiliation in adolescence. Journal of Adolescence, 9, pp73-96. http://dx.doi.org/10.1016/S0140-1971(86)80029-X

Bruner, J. (1960). The Process of Education. Cambridge MA: Harvard University Press.

Bruner, J. (1996). The Culture and Education. Cambridge MA: Harvard University Press.

Calhoun, C., Light, D. \& Keller, S. (1997). Sociology. (Seven Edition). New York: McGraw-Hill Inc.

Cargan, L. \& Ballantine, J. H. (1985). Sociological Footprints. Introduction Rereading in Sociology. (Third Edition). Wadsworth Publishing Company. California: Belmont.

Clark, D. (1996). Schools as Learning Communities: Transforming Education. Cassell: New York.

Clammer, J. (1996). Values and Development in Southeast Asia. Pelanduk Publications: Malaysia.

Cheng, Y. C. (2005). New Paradigm for Re-engineering Education. Globalization, Localization and Individualization. Netherlands: Springer.

Coleman, J. W. \& Cressey, D. R. (1993). Social Problems. (Fifth Edition). New York: Harper Collins College Publishers.

Cooley, C. H.(2009). The Process of Social Change. In Grundmann, R. \& Stehr, N. (Editors). Society: Critical Concepts in Sociology. Volume II Classical Theories of Society. London: Routledge. (Page 95-109)

DeCenzo, D. A. \& Silhanek, B. (2002). Human Relations Personal \& Professional Development. (Second Edition). Pearson Education Malaysia: Prentice Hall Upper Saddle River.

Dewey, John. (1938). Experience and Education. New York: Touchstone.

Dewey, John. (1966). Democracy and Education. An Introduction to the Philosophy of Education. New York: Free Press.

Dimitriadis, G. \& Kimberelis, G. Theory for Education (2006). Routledge: London.

Durkheim, E. (1958). Education and Sociology. London: The Free Press. Collier Macmillan Publishers.

Duval, S., \& Wicklund, R. A. (1972). A Theory of Objective Self-Awareness. New York: Academic Press.

Dwyer, P.D. \& Minnegal, M. (2010). Theorizing Social Change. Journal of the Royal Anthropolical Institute (N.S.) 16, pp629-645. 
Edgar, A. \& Sedgwick, P. (Editors). (2008). Cultural Theory: The Key Concepts. (Second Edition). London: Routledge Publishing.

Etzioni, A. (1991). A Responsive Society: Collected Essays on Guiding Deliberate Social Change. Oxford: San Francisco, Jossey-Bass Publishers.

Freud, S. (1938). The Basic Writings of Sigmund Freud. Translated by A. A. Bill. New York: Modern Library.

Gellens, R. J. \& Levine, A. (1995). Sociology: An Introduction. (Fifth Edition). New York: McGraw-Hill, Inc.

Gecas, V \& Seff, M. A. (1990). Families \& Adolescents: A Review of the 1980s. Journal of Marriage and the Family, 52: pp 941-958. http://dx.doi.org/10.2307/353312

Goleman, D. (2006). Social Intelligence. The New Science of Human Relationships. Bantam Book: New York.

Gonyea, R. M. (2006). The Relationship between Student Engagement \& Selected Desirable Outcomes in the First Year of College. Paper Presented at the 46th Annual Association for Institution Research Forum Chicago may 2006.

Goode, E. (1984). Sociology. Englewood Cliffs, New Jersey: Prentice-Hall Inc.

Gorrod, A. C., Smulyan, L., Powers, S. I. \& Kilkenny, R. (2002). Adolescent Portraits, Identity, Relationship \& Challenges. (Fourth Edition). Boston: Allyn \& Bacon.

Griswold, W. (2008). Cultures \& Societies in a Changing World. (Third Edition). Singapore: Pine Forge Press.

Grusec, J. \& Hastings, P. D. (2007). (Editors). Handbook of Socialization Theory and Research. New York: The Guilford Press.

Gubrium, J. F. \& Holstein, J. A. (2002). (Editors). Handbook of Interview Research: Context \& Method. USA: SAGE Publications.

Hall, E. \& Hall, C. (1988). Human Relations Education. Routledge: London.

Hamilton, J. A. (1987). Dress as A Cultural Sub-system: A Unifying Meta Theory for Clothing and Textiles. Clothing and Textiles Research Journal. 6 (1) pp 1-7.

Hamilton, S. F. \& Hamilton, M. A. (2006). School, Work and Emerging Adulthood in J. J. Arnett \& J. L. Tanner (Eds)., Coming of Age in the 21st Century: The Lives and Contexts of Emerging Adults. (pp 257-277). Washington, DC: American Psychological Association.

Haralambos, M. \& Heald, R. M. (1985). Sociology: Themes Perspectives. (Second Edition). Boston: McGraw-Hill

Harter, S. (1996). Teachers \& Classmate Influences on Scholastic Motivation, Self-esteem and Level of voice in adolescents. In J. Juvonen \& K. Wentzel (Eds). Social Motivations: Understanding Children's School Adjustment. pp11-42. New York: Cambridge University Press.

Hodges, E. V., Bolvin, M., Vitaro, E., \& Bukowski, W.M. (1999). The Power of Friendship: Protection against an escalating cycle of peer Victimization. Development Psychology. 35, 94-101. http://dx.doi.org/10.1037/0012-1649.35.1.94

Holborn, M. \& Haralambos, M. (2008). Sociology Themes \& Perspectives. (Seventh Edition). London: Collins Education Harper Collins Publications Limited.

Hoover, J. D. (2002). Effective Small Group \& Team Communication. USA: Harcourt College Publishers.

Houle, C. (1972). The Design of Education. San Francisco: Jossey Bass.

Hughes, M. \& Kroehler, C. J. (2009). Sociology the Core. (Ninth Edition). Boston: McGraw Hill Higher Education.

Hurn, C.J.(1978). The Limits and Possibilities of Schooling. An Introduction to Sociology of Education. Boston: Allyn \& Bacon Inc.

Innes, R. B. (2004). Reconstructing Undergraduate Education Using Learning Science to Design Effective Courses. London: Lawrence Erlbaum Associates Publishers Mahwah, New Jersey.

Jenkin, A; Breen, R.\& Lindsay, R.(2003). Reshaping Teaching in Higher Education; Linking Teaching with research. London : Routledge.

Johnson, A. G. (1996). Human Arrangements: An Introduction to Sociology. (Fourth Edition). USA: Brown \& Benchmark Publishers.

Joseph, M. (1986). Sociology for Everyone. United Kingdom: Polity Press. 
Killen, J., \& Wainryb, C. (2000). Independences and Interdependence in Diverse Cultural Context. In S. Harkness, C. Racff, \& C. M. Super (Eds). Variability in the Social Construction of the Child (pp5-21), San Francisco : Jossey-Bass.

Kottler, J. A. \& Carlson, M. E. (2010). Learning Group Leadership: An Experiential Approach. (Second Edition). London: SAGE Publications, Inc.

Lau, L. K. (2003). Institutional Factors Affecting Student Retention. Education. Vol. 124. No.1. USA: EBSCO Publishing. pp126-136.

Lauer, R. (1984). Perspectives on Social Change. (Third Edition). Boston: Allyn \& Bacon.

Lauer, R. H. \& Lauer, J. C. (2000). Marriage and Family: The Quest for Intimacy. New York: McGraw-Hill.

Mann, A. (2003). Relationships Matter: Impact of Parental, Peer factors on teen, young adult substance abuse. NIDA Notes.18 (2): pp11-13. http://dx.doi.org/10.1151/v18i2RMIPPFTYASA

Matheson, D and Wells, P. (1999). Chapter 1: What is Education? In Matheson, D. and Grosvenor, I. (Editors). (1999). An Introduction to the Study of Education.pp1-14. London: David Fulton Publishers.

Matheson, D. and Grosvenor, I. (Editors.) (1999). An Introduction to the Study of Education. London: David Fulton Publisher.

McIntyre, L. J. (2008). The Practical Skeptic Core Concepts in Sociology. (Fourth Edition). Boston: McGraw-Hill Higher Education.

Morshidi, S. (2005). Working Paper Transnational Higher Education in Malaysia: Balancing benefits and concerns through regulations. USM :Penang

Morshidi, S. (2006). (Series Editor). Muhamad Jantan, Chan Huan Chiang, Suheimi Shahnon and Suzyrman Sibly (Editors). Enhancing Quality of Faculty in private Higher Education Institutions in Malaysia. Monograph 9/2006 Institut Penyelidikan Pendidikan Tinggi Negara, Malaysia 2006

Moore, R. (2004). Education \& Society. Issues and Explanations in the Sociology of Education. UK: Polity Press.

Mulkey, L. M. (1993). Sociology of Education. Theoretical and Empirical Investigation. New York: Harcourt Brace Jovanorich College Publishers.

Muuss, R. E \& Porton, H. D. (1998). Adolescent Behavior \& Society. A Book of Reading. (Fifth Edition). Boston: McGraw-Hill College.

Newman, D. M. (2006). Sociology. Exploring the Architecture of Everyday Life. (Sixth Edition). United Kingdom: Sage Publications.

Neubeck, K. J and Glasberg, D.S. (2005). Sociology Diversity, Conflict and Change. New York: Mc Graw Hill Druckman.

O’Donnell, G. (1994). Mastering Sociology. (Third Edition). London: McMillan Press Ltd.

Pascarella, E. T. and Terenzini, P. T. (1991). How College Affects Students. Findings and Insights from Twenty Years of Research. San Francisco: Jossey-Bass Publishers.

Pascarella, E. T. and Terenzini, P. T. (2005). How College Affects Students. USA: Jossey-Bass A Wiley Imprint.

Ritzer, G. (2008). Contemporary Sociological Theory \& its Classical Roots. New York, McGraw Hall

Robinson, N. M. (1997). The Role of Universities and Colleges in Educating Gifted Undergraduates. Peabody Journal of Education. Vo. 72 (3 \& 4) pp 217-236. http://dx.doi.org/10.1080/0161956X.1997.9681875

Rogoff, B. (1997). Evaluating Development in the process of Participation: Theory, Methods \& Practice Building on each other. E. Amsel, \& K. A. Renninger (Eds). Change and Development: Issues of theory, methods and application (pp 205-285). Mahwah, New Jersey: Erlbaum.

Rose, R. (1999). Chapter 5: Children's Rights and Adult responsibilities. In Matheson, D. and Grosvenor, I. (editors). (1999). An introduction to the study of Education. pp59-69. London : David Fulton Publishers.

Rury, J, L. (2009). Education and Social Change. Contours in The History of American Schooling. (Third Edition). New York: Routledge.

Sanderson, S. K. (1991). Macro-sociology: An Introduction to Human Societies. (Second Edition). New York: Harper Collins Publishers, Inc. 
Sandstrom, K. L, Martin, D. D. \& Fine, G. A. (2003). Symbols, Selves \& Social Reality. A Symbolic Interactionist Approach to Social Psychology \& Sociology. Los Angeles, California: Roxbury Publishing Company.

Salter, D. W., Junce, R., Irvin, S. D. (2004). NASPA Journal. Vol. 41. No.4, summer 2004. Campus Social Climate Correlates of Environment Type Dimensions. pp 742-759.

Schaefer, R. T. (2000). Sociology: A Brief Introduction. (Third Edition). New York: The McGraw Hill Companies Inc.

Schaefer, R. T. and Lamm, R. P. (2003). Sociology: A Brief Introduction. (Eighth Edition). New York: The McGraw Hill Companies.Inc.

Schriver, J. M. (2004). Human Behavior and the Social Environment. Shifting Paradigms in Essential Knowledge for Social Work Practice. (Fourth Edition). USA: Pearson Education, Inc.

Schuckit, M. A. (1984). Drug \& Alcohol Abuse: A Critical Guide to Diagnosis and Treatment. (Second Edition). New York : Plenum Press.

Seltzer, T \& Bentley, K.S. (1999). The Creative Age: Knowledge and Skills for the New Economy. London: Demos

Slavin, R. E., Hurley, E. A. \& Chamberlain, A. (2003). Cooperative learning and Achievement: Theory \& Research in W. Reynolds \& G. Miller (Eds). Handbook of Psychology. Vo. 7, Educational Psychology, pp177-198. New York: Wiley.

Smith, P. \& Riley, A. (2009). Cultural Theory: An Introduction. (Second Edition). USA: Blackwell Publishing.

Smelser, N. J. (1988). Sociology. (Third Edition). Englewood Cliffs. New Jersey: Prentice-Hall.

Spark, M. (1961). The Prime of Miss Jean Brodie. London: Macmillan.

Stark, R. \& Bainbridge, W. S. (1987). A Theory of Religion. New York: Peter Lang.

Strauss, R. (1976). “Alcoholism \& problem Drinking” in Robert K. Merton \& Robert Nisbet (Eds). Contemporary Social Problems. (Fourth Edition). New York: Harcourt Brace Joranovich, pp 181-127.

Tepperman, L. \& Richardson, R. J. 91991). An Introduction to Sociology. The Social World. (Second Edition). New York: McGraw-Hill.

Tischler, H. (1996). Introduction to Sociology. (Fifth Edition). USA: The Harcourt Press.

Turner J. H. (1994). Sociology Concepts and Uses. New York: McGraw Hill Inc.

Tudge, J., Shanahan, M. J. \& Valsiner, J. (1997). Comparison in Human Development. London: Cambridge University Press.

Vago, S. (1996). Social Change. (Third Edition). New Jersey: Prentice Hall

Vaughan, G. M. \& Hogg, M. A. (2008). Introduction to Social Psychology. (Fifth Edition). Australia: Pearson Education.

Warner, R. S. (1993). Work In Progress toward A New Paradigm for Sociological Study of Religion in the United States. American Journal of Sociology, 98: pp1044-1093. http://dx.doi.org/10.1086/230139

Weidman, J. (1989). Undergraduates Socialization: A Conceptual Approach. Higher Education Handbook of Theory \& Research. Vol. 5, pp289-322. New York: Agathon Press.

Wilkins, E. J. (1973). Elements of Sociology. London: MacDonald \& Evans Ltd.

Zailan, M. (2007). (Editor). 50 Tahun Pembangunan Pendidikan Tinggi di Malaysia (1957 - 2007). Penang: Penerbit University Sciences Malaysia.

Zanden, V. \& Wilfried, J. (1990). The Social Experience: An Introduction to Sociology. (Second Edition). New York: McGraw Hill Publishing Company. 